\title{
Effects of quail (Coturnix japonica) egg diet on both the blood sugar and the lipid profile of alloxan induced diabetic albino rats.
}

\author{
Umera AE ${ }^{1}$, Ejezie FE ${ }^{1}$, Ibegbu MD ${ }^{1 *}$, Ikekpeazu JE${ }^{1}$, Onyekwelu KC ${ }^{1}$, Ejezie $\mathrm{CS}^{2}$ \\ ${ }^{1}$ Department of Medical Biochemistry, College of Medicine, University of Nigeria, Enugu Campus (UNEC), Enugu, \\ Nigeria
}

${ }^{2}$ Department of Haematology and Immunology, College of Medicine, Ituku-Ozalla, Nigeria

\begin{abstract}
Quail eggs have been found useful in folk medicine in treatment of some diseases, but its consumption is not as common as chicken eggs amongst humans. This study was aimed at determining the dietary effects of quail eggs on blood sugar and lipid profile of alloxan induced diabetic rats. Quail egg samples were analysed for its various nutritional compositions using the Association of Official Analytic Chemistry (AOAC) methods. Quail eggs were administered to thirty six (36) alloxan induced diabetic rats, which were divided into nine (9) different groups of four (4) rats each per group at varied doses for a duration of seven (7), fourteen (14) and twenty one (21) days. Their blood sugar and lipid profile were determined using standard methods. Proximate analysis showed that quail egg could be a good source of protein, lipid and has high moisture content while it has minimal ash and carbohydrate contents. Rats treated with two (2) raw quail eggs showed the highest blood glucose lowering capacity and weight gain when compared with the insulin treated rats. Evaluation of the blood glucose at intervals (d 7, d 14, and d 21) showed that quail eggs could serve for mid-term and long term treatment of diabetes, but did not have any significant effects on the serum lipid profile of diabetic rats. It could be concluded that intake of quail egg diets either alone or as part of a therapeutic regime, could have beneficial effect in the prevention and management of diabetes mellitus.
\end{abstract}

Keywords: Quail eggs, Diabetes, Blood sugar, Lipid profile.

Accepted on September 24, 2018

\section{Introduction}

In human body, a regular energy source is a prerequisite for normal cell function. Glucose is the primary energy source of the body, which circulates in the blood as a mobilizable fuel source for cells [1,2]. Diabetes mellitus is a group of metabolic disorders characterized by high level of glucose in the blood resulting from defects in insulin secretion and/or increased cellular resistance to insulin [3]. Chronic hyperglycaemia and other metabolic disturbances of diabetes mellitus lead to longterm tissue and organ damage as well as dysfunction involving the eyes, kidneys, nervous and vascular systems [4].

Avian eggs are an inexpensive and highly nutritious food, providing 13 vitamins and 7 minerals [5], the composition of which can be affected by several factors such as diet, age, strain as well as environmental factors [6]. The eggs are conventional food containing nutrients that play fundamental roles beyond basic nutrition [7]. Eggs are of particular interest from a functionality point of view because they are excellent source of protein, moderate calorie, also inexpensive, these makes eggs affordable to good percentage of many populations [8]. However, eggs are a controversial food for nutritional experts and health agencies because of the saturated fat and cholesterol content [9]. This was based on the assumption that high dietary cholesterol consumption is associated with high blood cholesterol levels and cardiovascular disease [10].

Quail eggs are used in folk medicine. For instance, Chinese use quail eggs in the treatment of tuberculosis, asthma and diabetes and helps prevent kidney, liver, or gallbladder stones and even remove these types of stones [11]. In Japan, consumption of Japanese quail eggs has been claimed to improve metabolism; prevent stress; and help in the treatment of obesity, asthma, and various allergies [12]. In Brazil, there is a claim that it relieves many physiological disorders such as anaemia, tuberculosis, ulcers, hypertension, diabetes, arteriosclerosis, asthma and many other diseases [13]. Regular consumption of quail eggs has been shown to fight against many diseases, which includes digestive tract disorders such as stomach ulcers, it strengthens the immune system, promotes memory health, increases brain activity and stabilizes the nervous system. This also is beneficial in anaemia management by increasing the level of haemoglobin in the body while removing toxins and heavy metals. The nutritional value of quail eggs is higher than those offered by other eggs in being a rich sources of antioxidants, 
minerals, and vitamins [14]. The nutritional value of quail eggs is 3-4 times greater than chicken eggs and studies have shown that the shell of quail eggs consists of $90 \%$ calcium and in addition contains minerals like copper, fluorine, sulphur, silicon, zinc and stimulates hematopoietic function of bone marrow [15].

With the increasing search for natural remedies to diseases especially diabetes mellitus, this study was initiated to ascertain the effect of quail eggs on the blood sugar and lipid profile of alloxan induced diabetic albino rats.

\section{Materials and Methods}

\section{Sample collection}

Quail eggs (Coturnix coturnix japonica) were purchased from a poultry House in Enugu, Nigeria. For the purpose of this study 60 eggs were chosen randomly and four (4) were randomly selected and weighed to obtain an estimated average weight of each quail egg. The egg samples were carefully handled in an egg-box and transported to the laboratory.

\section{Proximate and elemental analysis}

The protein, fat and moisture content were evaluated using the method of the Association of Official Analytical Chemists [16]. The elemental analysis of the eggshell and the egg was done as described by Allen [17].

\section{Processing of eggs and egg shells for feeding of rats}

The de-shelled quail eggs were put in a non-stick frying pan and cooked for about $5 \mathrm{~min}$. The cooked egg was then placed into a drying rack in dehydrator and oven-dried for around $16-18 \mathrm{~h}$ at $70^{\circ} \mathrm{C}$ until completely brittle substance was obtained, which was pulverised into powder with blender and stored for use.

The egg shells were properly washed with distilled water in order to remove all adjacent egg content, oven dried for between $6-8 \mathrm{~h}$ at $70^{\circ} \mathrm{C}$ until completely brittle, and pulverised into powder and stored for use.

\section{Animal experiment}

This study was approved by the Faculty of Basic Medical Sciences animal research ethics committee. Thirty six (36) male albino rats weighing about $240 \mathrm{~g}$ were used for the experiment. The animals were purchased from Department of Human Physiology, University of Nigeria, Enugu Campus. The rats were allowed to acclimatize for $14 \mathrm{~d}$ and were assigned into nine groups with four rats each per group as described below. The rats were induced with diabetes and were maintained at $25 \pm 2{ }^{\circ} \mathrm{C}$ in a room with a $12 / 12 \mathrm{~h} \mathrm{light/dark}$ cycle and fed with standard rat chow and quail egg. Rats in groups 1-3 received standard rat chow while the rest received quail egg diet in addition.

\section{Administration of quail egg diet, insulin/collection of blood samples}

After diabetes induction, the rats of groups 4-9 were treated with different preparations of quail egg diet for $21 \mathrm{~d}$ as described below; while insulin (regular insulin) $40 \mathrm{IU} / \mathrm{ml}$ solution per $100 \mathrm{~g}$ body weight was administered daily for $21 \mathrm{~d}$ to group 3 rats.

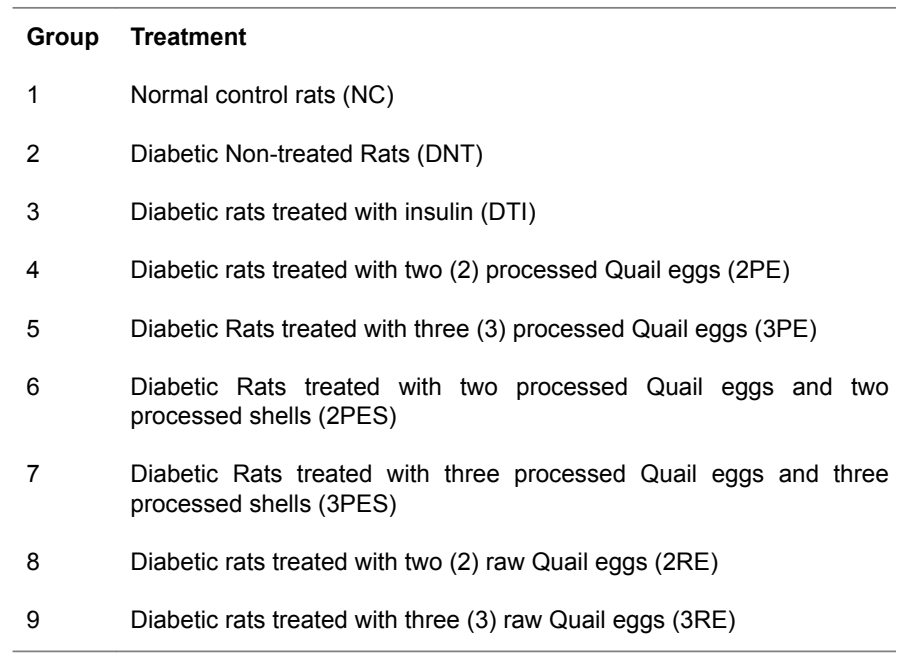

\section{Induction of diabetes}

The baseline blood glucose levels of the rats were determined before diabetes induction. Diabetes was induced on the rats by intra-peritoneal (IP) injection of $150 \mathrm{mg} / \mathrm{kg}$ body weight of alloxan monohydrate solution [18].

\section{Sample analyses}

The blood glucose levels of the rats were determined using glucometer. The body weights of the rats before induction, after induction and at intervals during the feed administration were recorded. The blood glucose levels of the rats were determined on $\mathrm{d} 1,7,14$ and 21 during the administration of the processed and raw quail egg diets. After $21 \mathrm{~d}$, the rats were sacrificed and the blood samples collected for glucose estimation, also serum prepared from the blood samples for lipid profile analysis. total cholesterol (TC), triglycerides (TG), high-density lipoprotein (HDL) and low-density lipoprotein (LDL) were determined using Hitachi 704 Analyzer according to the manufacturer's instruction.

\section{Data analysis}

The Statistical Package for Social Science (SPSS) computer software version 17 was used for data analysis. The results of the tests were analysed using analysis of variance (ANOVA) and student's t-test at $95 \%$ confidence interval with $p$ value of $\leq 0.05$ been considered as significant.

\section{Results}

The results of the proximate composition revealed that the quail eggs were good sources of protein, lipids and with high 
Effects of quail (Coturnix japonica) egg diet on both the blood sugar and the lipid profile of alloxan induced diabetic albino rats.

moisture content. However, the ash and carbohydrate contents were minimal (Table 1).

The evaluation of elemental composition revealed that the whole egg (both the egg white and yoke) was rich in calcium $(150.50 \pm 0.71 \mathrm{mg} / 100 \mathrm{~g})$, zinc $(43.73 \pm 0.04 \mathrm{mg} / 100 \mathrm{~g})$, iron $(78.90 \pm 0.14 \mathrm{mg} / 100 \mathrm{~g})$, phosphorous $(120.56 \pm 0.62 \mathrm{mg} / 100$ g) and magnesium $(105.50 \pm 0.71 \mathrm{mg} / 100 \mathrm{~g}$ while the shell also revealed that it was equally rich in calcium $(300.25 \pm 0.35$ $\mathrm{mg} / 100 \mathrm{~g})$, zinc $(38.13 \pm 0.88 \mathrm{mg} / 100 \mathrm{~g})$, Iron $(175.70 \pm 0.42$ $\mathrm{mg} / 100 \mathrm{~g})$ and magnesium $(78.15 \pm 0.21 \mathrm{mg} / 100 \mathrm{~g})$. However, the copper, potassium and manganese contents were minimal (Table 2).

Table 1. Proximate composition of Quail egg, Coturnix japonica.

\begin{tabular}{lll}
\hline Parameter & \multicolumn{2}{l}{ Value $(\mathbf{g} / \mathbf{1 0 0 g})$} \\
\cline { 2 - 3 } & Albumen & Yolk \\
\hline Protein & $9.4 \pm 0.04$ & $15.10 \pm 0.16$ \\
\hline Lipid content & $0.41 \pm 0.05$ & $31.39 \pm 0.26$ \\
\hline Ash content & $1.13 \pm 0.09$ & $1.99 \pm 0.09$ \\
\hline Moisture & $88.48 \pm 0.36$ & $50.18 \pm 0.25$ \\
\hline Carbohydrate & $0.65 \pm 0.05$ & $1.08 \pm 0.25$ \\
\hline
\end{tabular}

Table 2. Elemental composition of quail egg (Coturnix japonica).

\begin{tabular}{lll}
\hline Parameter & \multicolumn{2}{l}{ Values $(\boldsymbol{\mu g} / \mathbf{g}$ or $\mathbf{m g} / \mathbf{l})$} \\
\cline { 2 - 3 } & Whole egg & Shell \\
\hline Calcium (Ca) & 1500.00 & 3000.00
\end{tabular}

\begin{tabular}{lll}
\hline Zinc $(\mathrm{Zn})$ & 43.75 & 38.15 \\
\hline Copper $(\mathrm{Cu})$ & 0.55 & 2.80 \\
\hline Iron (Fe) & 78.80 & 175.40 \\
\hline Phosphorous (P) & 120.12 & 0.14 \\
\hline Potassium (K) & 0.25 & 4.65 \\
\hline Magnesium (Mg) & 105 & 78 \\
\hline Manganese (Mn) & 1.23 & 0.22 \\
\hline Silicon (Si) & Nil & 2.93
\end{tabular}

Statistical analysis of the mean blood glucose levels at $\mathrm{d} 14$ and 21 after treatment of diabetic induced rats with quail egg showed that quail eggs were able to effectively lower the blood glucose to almost the same level with the control (group 1) and diabetic insulin treated rat (group 3) (Table 3).

Diabetes is associated with weight loss and the result of this study revealed that diabetic rats treated with two and three raw quail eggs respectively showed the best performance in terms body weight gain when compared with other quail egg treated rats (Table 4).

The lipid profile analysis revealed that quail egg treatment/ administration did not have any negative effect on the lipid profile level of diabetic rats but showed ability of reducing/ lowering the lipid profile, implying that quail egg diet could be a possible means of reducing the risk of heart disease or any risk of diabetic dyslipidaemia (Table 5).

Table 3. Blood glucose in $\mathrm{mg} / \mathrm{dl}$ of alloxan induced diabetes rats treated with insulin, processed and raw quail eggs.

\begin{tabular}{|c|c|c|c|c|c|}
\hline Group & Before induction (mg/dl) & D 1 induction (mg/dl) & D 7 induction (mg/dl) & D 14 induction (mg/dl) & D 21 induction (mg/dl) \\
\hline $1(\mathrm{NC})$ & $81.25 \pm 5.74$ & $121.75 \pm 1.31^{a}$ & $101.75 \pm 4.55^{a}$ & $85.50 \pm 3.57^{a}$ & $114.00 \pm 4.42^{\mathrm{a}}$ \\
\hline 2 (DNT) & $57.50 \pm 10.46$ & $255.75 \pm 53.51^{b}$ & $325.50 \pm 40.13^{b}$ & $381.25 \pm 38.23^{b}$ & $417.50 \pm 43.19^{b}$ \\
\hline 3 (DTI) & $58.75 \pm 11.10$ & $177.00 \pm 28.23^{c}$ & $170.75 \pm 21.85^{\mathrm{c}}$ & $189.00 \pm 19.48^{c}$ & $146.75 \pm 20.76^{c}$ \\
\hline 4 (2PE) & $86.50 \pm 3.80$ & $320.75 \pm 15.44^{\mathrm{bd}}$ & $219.25 \pm 29.44^{\mathrm{cb}}$ & $186.75 \pm 32.07^{c}$ & $135.50 \pm 23.70^{c}$ \\
\hline 5 (3PE) & $82.00 \pm 2.48$ & $464.25 \pm 57.12^{d}$ & $366.75 \pm 33.39^{b}$ & $287.00 \pm 26.80^{\mathrm{cb}}$ & $189.50 \pm 13.07^{c}$ \\
\hline 6 (2PES) & $105.00 \pm 7.65$ & $506.25 \pm 34.34 \mathrm{e}$ & $345.75 \pm 23.90^{b}$ & $233.25 \pm 29.40^{c b}$ & $113.00 \pm 8.04^{a}$ \\
\hline 7 (3PES) & $97.25 \pm 8.75$ & $386.75 \pm 61.45^{\mathrm{bd}}$ & $360.50 \pm 62.58^{b}$ & $294.50 \pm 51.95^{\mathrm{cb}}$ & $143.75 \pm 15.02^{c}$ \\
\hline 8 (2RE) & $79.75 \pm 9.63$ & $216.75 \pm 56.04^{b}$ & $268.00 \pm 57.80^{\mathrm{cb}}$ & $179.75 \pm 25.44^{c}$ & $107.00 \pm 3.79^{a}$ \\
\hline 9 (3RE) & $74.00 \pm 11.45$ & $374.75 \pm 64.43^{\mathrm{bd}}$ & $343.00 \pm 81.54^{b}$ & $222.00 \pm 22.55^{\mathrm{cb}}$ & $124.25 \pm 2.46^{\mathrm{ac}}$ \\
\hline
\end{tabular}

Where: $a$ is significant $(p<0.05)$ when compared with normal control (Group 1$)$; b is significant $(p<0.05)$ when compared with diabetic non-treated control $($ Group 2$)$; $c$ is significant $(p<0.05)$ when compared with insulin treated control (Group 3).

Table 4. Weight ( $g$ ) of alloxan induced diabetes rats treated with insulin, processed and raw quail eggs.

\begin{tabular}{|c|c|c|c|c|}
\hline Group & Before induction & $1 \mathrm{w}$ after induction & $2 \mathrm{w}$ after induction & $3 \mathrm{w}$ after induction \\
\hline $1(\mathrm{NC})$ & $150.98 \pm 7.38$ & $170.00 \pm 7.18$ & $194.35 \pm 5.41$ & $211.53 \pm 6.55$ \\
\hline
\end{tabular}




\begin{tabular}{|c|c|c|c|c|}
\hline 2 (DNT) & $193.58 \pm 3.56$ & $188.20 \pm 4.42^{*}$ & $178.40 \pm 3.48^{*}$ & $173.23 \pm 4.59^{*}$ \\
\hline 3 (DTI) & $168.00 \pm 8.49$ & $181.95 \pm 9.11$ & $184.58 \pm 4.95$ & $187.58 \pm 5.03$ \\
\hline $4(2 \mathrm{PE})$ & $155.53 \pm 5.44$ & $155.50 \pm 5.42^{*}$ & $164.15 \pm 6.49$ & $168.65 \pm 6.03$ \\
\hline $5(3 \mathrm{PE})$ & $187.28 \pm 13.70$ & $189.63 \pm 11.29$ & $192.88 \pm 12.55$ & $195.30 \pm 10.37$ \\
\hline $6(2 \mathrm{PES})$ & $165.80 \pm 11.55$ & $174.38 \pm 5.94$ & $177.90 \pm 6.63$ & $181.95 \pm 7.20$ \\
\hline 7(3PES) & $189.90 \pm 7.33$ & $197.33 \pm 12.51$ & $191.53 \pm 9.01^{*}$ & $192.15 \pm 9.11$ \\
\hline 8 (2RE) & $135.40 \pm 9.93$ & $133.40 \pm 11.56^{*}$ & $140.25 \pm 12.08$ & $145.28 \pm 15.08$ \\
\hline 9 (3RE) & $198.40 \pm 8.61$ & $204.33 \pm 9.24$ & $213.23 \pm 6.99$ & $221.23 \pm 5.01$ \\
\hline
\end{tabular}

Table 5. Lipid profile of all the groups after treatment with processed and raw quail egg, quail egg shell.

\begin{tabular}{llllll}
\hline Group & Cholesterol $(\mathbf{m g} / \mathbf{d l})$ & HDL $(\mathbf{m g} / \mathbf{d l})$ & TG $(\mathbf{m g} / \mathbf{d l})$ & VLDL $(\mathbf{m g} / \mathbf{d l})$ & LDL $(\mathbf{m g} / \mathbf{d l})$ \\
\hline $1(\mathrm{NC})$ & $108.50 \pm 4.79^{\mathrm{a}}$ & $37.75 \pm 6.87^{\mathrm{a}}$ & $61.00 \pm 7.38^{\mathrm{a}}$ & $15.25 \pm 1.31$ & $38.00 \pm 8.66^{\mathrm{a}}$ \\
\hline $2(\mathrm{DNT})$ & $135.00 \pm 5.93^{\mathrm{b}}$ & $59.00 \pm 9.70^{\mathrm{b}}$ & $81.25 \pm 10.08^{\mathrm{b}}$ & $16.25 \pm 2.02$ & $59.75 \pm 5.89^{\mathrm{b}}$ \\
\hline $3(\mathrm{DTI})$ & $103.00 \pm 8.57^{\mathrm{a}}$ & $50.75 \pm 6.87^{\mathrm{c}}$ & $680.00 \pm 5.28^{\mathrm{c}}$ & $16.00 \pm 1.08$ & $36.25 \pm 4.21^{\mathrm{c}}$ \\
\hline $4(2 \mathrm{PE})$ & $100.25 \pm 5.14^{\mathrm{a}}$ & $38.50 \pm 2.25$ & $72.75 \pm 10.73$ & $14.50 \pm 2.10$ & $46.50 \pm 2.40^{\mathrm{c}}$ \\
\hline $5(3 \mathrm{PE})$ & $81.75 \pm 9.82^{\mathrm{a}}$ & $36.50 \pm 5.14$ & $71.00 \pm 24.86$ & $14.25 \pm 5.02$ & $23.75 \pm 2.63$ \\
\hline $6(2 \mathrm{PES})$ & $105.75 \pm 14.21^{\mathrm{a}}$ & $52.25 \pm 7.43^{\mathrm{c}}$ & $91.25 \pm 16.64$ & $18.25 \pm 3.30$ & $35.25 \pm 7.55^{\mathrm{c}}$ \\
\hline $7(3 \mathrm{PES})$ & $88.00 \pm 5.18^{\mathrm{a}}$ & $45.50 \pm 3.59^{\mathrm{c}}$ & $58.50 \pm 10.12$ & $12.00 \pm 2.16$ & $30.50 \pm 6.22$ \\
\hline $8(2 \mathrm{RE})$ & $70.75 \pm 5.02^{\mathrm{a}}$ & $29.25 \pm 3.94$ & $62.75 \pm 10.66$ & $12.50 \pm 2.10$ & $29.00 \pm 0.71$ \\
\hline $9(3 \mathrm{RE})$ & $89.00 \pm 4.04^{\mathrm{a}}$ & $44.25 \pm 1.03$ & $84.75 \pm 9.08$ & $17.00 \pm 1.83$ & $27.75 \pm 3.25$ \\
\hline${ }^{* *}$ Normal Range: & $86.19-144.76$ & $50.00-56.67$ & $47.57-108.11$ & $9.51-21.62$ & $11.24-77.46$ \\
\hline
\end{tabular}

Values are statistical significant at $p<0.05$ ) ${ }^{* *}$ reference values for the serum lipid profile of albino rats (Rattus norvegicus) of varied ages and sexes [19]; Where: a is significant $(p<0.05)$ when compared with normal control (Group 1); $b$ is significant $(p<0.05)$ when compared with diabetic non-treated control $(G$ roup 2); $c$ is significant $(p<0.05)$ when compared with insulin treated control (Group 3).

\section{Discussion}

Quail eggs are considered a delicacy in many parts of the world and have been used for medicinal purposes for hundreds of years. The results of the proximate composition revealed that quail eggs could be a good source of protein and lipids; though, with minimal ash and carbohydrate contents. Similar findings have been reported by Tolik et al., Dudusola and Genchev [20-22]. On the contrary, Sinanoglou et al. [23] reported lower fat and higher ash contents in quail egg yolk. This study (Table 2) showed that the whole egg was rich in calcium and magnesium, while the egg shell had higher content of calcium. The whole egg showed high content of magnesium and phosphorus compared to the egg shell; similar observation was made by Shanaway [24]. Abduljaleel et al. [25] in their study showed higher manganese, iron, zinc and copper content in quail egg than what was obtained in this study. The difference in mineral content could be as a result of the major constituent of feed used in feeding the birds or the different environment the birds were exposed to as avian eggs mineral compositions have been reported to vary as a result of region of origin [26].
On $\mathrm{d} 7$ of the treatment, it was observed that insulin treated group showed the earliest sign of recovery unlike other groups which implied that the groups treated with the quail eggs did not have a short term effect on blood glucose level. On days 14 and 21 , no statistical difference was observed between normal control group, diabetic rats treated with insulin and most of other groups treated with quail egg. At this point the quail egg had almost the same effect as insulin with group 8 (raw quail egg diet) showing the lowest blood glucose level (Table 3). This showed that the administration of quail egg for $21 \mathrm{~d}$ lowered the blood glucose level of diabetic rats to the level of the normal control group, which suggested that long term beneficial effect of quail egg in diabetes treatment. It was also an indication that quail egg treatments had the same effect as insulin and could be substituted for insulin in the long-term effect of diabetes management and treatment. The hypoglycaemic effect of quail egg may be attributed probably to the presence of minerals and amino acids which play key role in blood glucose homeostasis by regulating the key enzymes involved in glucose metabolism [27]. On the contrary, Lontchi-Yimagou et al. [28] reported that administration of 
quail eggs for $16 \mathrm{~d}$ in diabetic rats had no effect on blood glucose.

Diabetes mellitus is associated with weight loss. In this study, weight loss was recorded in $\mathrm{d} 7$ and 14 in some alloxan induced diabetic groups and this resembles a common observation in clinical diabetes. On d 21, all the treated groups recorded weight gain which could be seen in normal rats (Table 4). This implies that the effect of weight loss associated with diabetes had been effectively addressed by administration of quail egg. This observation showed that quail egg could be effectively used for both mid-term and long-term treatment of weight loss associated with diabetes. The high protein content of quail egg could be attributed to the observed weight gain [29].

This study observed that administration of quail egg to alloxan induced diabetic albino rats did not have any negative effect on the lipid profile of diabetic rats but has the ability of lowering the lipid profile (Table 5) thereby reducing the risk of diabetic dyslipidaemia. This finding is in agreement with the study carried out by Aba et al. [30] which showed that alloxanized rats that were administered with quail egg solution demonstrated hypolipidemia. Lontchi-Yimagou et al. [28] in their study showed that total cholesterol and triglyceride levels were higher in diabetic rats receiving quail eggs compared to non-treated diabetic rats and diabetic untreated rats respectively. The finding here suggests that intake of quail egg diets either alone or as part of a therapeutic regime, could have beneficial effect in prevention and management of diabetes mellitus.

\section{References}

1. Piero MN. Diabetes mellitus-a devastating metabolic disorder. Asian J Biomed Pharm. Sci 2015; 4: 1-7.

2. McMillan T, Girgis R, Sellers EAC. Neonatal diabetes and protein losing enteropathy: a case report. BMC Med Genet 2016; 17: 32.

3. American Diabetes Association. Diagnosis and classification of diabetes mellitus. Diabetes Care 2012; 35: 64-71.

4. Nathan DM, Cleary PA, Backlund JY, Genuth SM, Lachin JM, Orchard TJ, Raskin P, Zinman B. Intensive diabetes treatment and cardiovascular disease in patients with type 1 diabetes. N Engl J Med 2005; 353: 2643-2653.

5. USDA National Nutrient Database for Standard Reference. Basic Rep 01123, Egg, whole, raw, fresh 2018.

6. Fraeye I, Bruneel C, Lemahieu C, Buyse J, Muylaert K, Foubert I. Dietary enrichment of eggs with omega-3 fatty acids: a review. Food Res Int 2012; 48: 961-969.

7. Herron KL, Fernandez ML. Are the current dietary guidelines regarding egg consumption appropriate? J Nutr 2004; 134: 187-190.

8. Carrillo S, Rios V.H, Calvo C, Carranco ME, Casas M, Perez-Gil F. N-3 fatty acid content in eggs laid by hens fed with marine algae and sardine oil and stored at different times and temperatures. J Appl Phycol 2012; 24: 593-599.

9. Li Y, Zhou C, Zhou X, Li L. Egg consumption and risk cardiovascular diseases and diabetes: a meta-analysis. Atherosclerosis 2013; 229: 524-530.

10. Eilat-Adar S, Sinai T, Yosefy C, Henkin Y. Nutritional recommendations for cardiovascular disease prevention. Nutrients 2013; 5: 3646-3683.

11. Tanasorn T, Wanna T, Wattasit S. Nutrient benefits of quail (Coturnix Coturnix japonica) eggs. Int J Sci Res Publ 2013; 5: 1-8.

12. Truffier JC. Approach to treatment of allergy by consumption of quail egg. La Clinique 1978; 22: 2-4.

13. Anca T, Vacaru-opris I, Teusan V. Aspects regarding some morphological values of the domestic quail eggs (Coturnix coturnix japonica). Lucr Stiint Zooteh Biotech 2008; 41: 709-716.

14. Lalwani P. Quail Egg Nutrition. 2011 http:// www.buzzle.com/articles/quailegg-nutrition.html

15. Tunsaringkarn T, Tungjaroenchai W, Siriwong, W. Nutrient benefits of quail (Coturnixcoturnix japonica) eggs. Int J Sci Res Publ 2013; 3: 1-8.

16. AOAC. Official Method of Analysis of AOAC. International 18th Edition. Inc. Maryland 20877-2417, USA, 2005; 2-74.

17. Allen WF. A micro-Kjeldahl method for nitrogen determination. J Am Oil Chem Soc 1945; 8: 391-397.

18. Yanarday R, Colae H. Effect chard (Beta vulgaris L. varcicla) on blood glucose level in normal and alloxan induced diabetic rabbit. J. Ethnopham 1998; 4: 309-311.

19. Ihedioha JI, Noel-Uneke OA, Ihedioha TE. Reference values for the serum lipid profile of albino rats (Rattusnorvegicus) of varied ages and sexes. Compar Clin Pathol 2013; 22: 93-99.

20. Tolik D, Polawska E, Charuta A, Nowaczewski S, Cooper R. Characteristics of egg parts,chemical composition and nutritive value of Japanese quail eggs Folia biologica (Kraków) 2014; 62: 287-292.

21. Dudusola IO. Comparative evaluation of internal andexternal qualities of eggs from quail and guinea fowl. Int Res J Plant Sci 2010; 1: 112-115.

22. Genchev A. Quality and composition of Japanese quail eggs (Coturnix japonica). TJS 2012; 10: 91-101.

23. Sinanoglou VJ, Strati IF, Miniadis-Meimaroglou S. Lipid, fatty acid and carotenoid content of edible egg yolks from avian species: a comparative study. Food Chem 2011; 124: 971-977.

24. Shanawaym M. Quail production systems. Food and Agriculture Organization of the United Nations Rome 1994; 1-135.

25. Abduljaleel SA, Shuhaimi-Othman M, Babji A. Variation in trace elements levels among chicken, quail, guinea fowl and pigeon eggshell and egg content. Res J Env Toxicol 2011; 5: 301-308. 
26. Szablewski T, Gornowicz E, Stuper-szablewska K, Kaczmarek A, Cegielska-radziejewska R. Mineral composition of contents in table eggs from autochthonous hen breeds bred under ecological conditions. ZYWNOSC Nauka Technologia Jakosc 2013; 5: 42-51.

27. Broadhurst CL. Nutrition and non-insulin diabetes mellitus form by the combined administration of streptozotocin or alloxan and poly (adenosine diphosphate ribose). Engg 1997; 2: 125.

28. Lontchi-Yimagou E, Tanya A, Tchankou C, Ngondi J, Oben J. Metabolic effects of quail eggs in diabetesinduced rats: comparison with chicken eggs. Food Nutr Res 2016; 60: 32530.

29. Augustine J, Crispen P, Kudakwashe C, Philip T. Nutritional compositions of Japanese quail (Coturnix coturnix japonica) breed lines raised on a basal poultry ration under farm conditions in Ruwa, Zimbabwe. Cogent Food Agr 2018; 4: 1473009.

30. Aba PE, Onah JA. Evaluation of the possible hypolipidemic properties of quail egg on alloxan-induced diabetic rats. J Worlds Poult Res 2015; 5: 84-89.

\section{*Correspondence to}

Ibegbu MD

Department of Medical Biochemistry

College of Medicine

University of Nigeria, Enugu Campus (UNEC)

Nigeria 